\title{
Development of tools for internal control and leadership recognition in working groups
}

\author{
Biedermann, Anna ${ }^{a}$; Agudo-Valiente, José María ${ }^{b}$; López-Forniés, Ignacio ${ }^{c}$; Sánchez- \\ Valverde, María Belén ${ }^{d}$ and Pardina Carrera, Antonio \\ ${ }^{\mathrm{a} D e s i g n}$ and Manufacturing Engineering, University of Zaragoza, Spain, ${ }^{\mathrm{b}}$ Management \\ Department, University of Zaragoza, Spain, 'Design and Manufacturing Engineering, \\ University of Zaragoza, Spain, ${ }^{\mathrm{d}}$ Department of Statistical Methods, University of Zaragoza, \\ Spain, ${ }^{\mathrm{e}}$ Department of Electrical Engineering, University of Zaragoza, Spain.
}

\begin{abstract}
This paper presents the state of teaching experience conducted during the last seven years by a group of teachers. These professors simultaneously teach five subjects in the framework of the EHEA of the Degree of Engineering of Industrial Design and Product Development at the University of Zaragoza.
\end{abstract}

The applied teaching methodology includes guarantee of teaching quality and learning system based on series of indicators that have been defined and improved over the years. This document reflects the results of the module work during the last academic year 2015-2016, during which the follow-up of group work has been implemented based on meeting records of the group meetings. In these meeting records the students have reflected the evolution of their work and the agreements taken, being supervised regularly by the teachers. As a result of this action, a substantial improvement has been achieved in the functioning of working groups that, due to their particular circumstances, could be problematic, allowing the teaching team greater control of internal conflicts. Additionally, the system also serves a second objective: fostering leadership in the group by rewarding the individual final grade for proactive behavior and punishing dishonest behaviors among peers.

Keywords: modular teaching; quality guarantee; continuous improvement in teaching and learning; collaborative learning; project-based learning. 


\section{Introduction}

From the academic year 2009-2010 to the present, within the framework of the EHEA of the Degree of Engineering of Industrial Design and Product Development at the University of Zaragoza, the group of professors who teach the five subjects (Creativity, Graphic Design and Comunication, Statistics, Electricity and Economic Aspects) simultaneously, with the same group of students of the second year and second semester teaching period, has been applying a system of quality guarantee for teaching and learning. This teaching team has since then developed the work methodology by modules (Agudo et al., 2011; Miralves et al., 2011; Manchado y López, 2012; López y Manchado, 2013; Serrano et al., 2013) in order to obtain a more practical training, thus promoting students learning. This work basically consists of a module project (MP) in which the group of four or five students must integrate the multidisciplinary knowledge of the five subjects of the semester, taking into account that they must achieve global objectives of the work as well as individual objectives of the respective subjects (Agudo et al., 2011). The overall objective of the project is to prepare the student for the professional reality he/she will face at the end of his/her studies (López and Manchado, 2013). Because it is in the working world where this capacity of coordination of the different areas of the company and its integration in a common work is demanded.

The developed principles of all the work are based on Project-Based Learning (PBL) and Collaborative Learning (CL) (Bará J., Domingo J. and Valero M. 2009; Bará J., Ruiz S. and Valero M. 2009; Bouhuijs PAJ, 2011; Herreroreder IA, 2013). Based on basic specifications of a common product to all groups and previously established by the teaching team, students must design and launch a new product to the market and in order to do it they develop a series of activities that they organize, program and supervise with the help of the team of teachers. The goal, as if it were a real business environment, is the development of a new product and its placing on the market with all that it entails.

The applied teaching methodology is based on the philosophy of continuous improvement, contemplating a series of indicators that have been defined and improved throughout all these years.

The indicators finally obtained correspond to the competences that must be acquired in the different subjects. In particular, they allow the evaluation of coordination and group work, the management of information, the evolution of its capacity for analysis and synthesis, as well as the ability to solve problems, concern for quality and general satisfaction. It also provides information on time management in the distribution of tasks throughout the project, the balance of requirements between subjects or coordination between teachers.

This system of quality guarantee in imparted teaching is annually reviewed by the team of teachers, establishing corrective actions based on the intended initial objectives. Past 
examples of these improvements have been: the joint evaluation of the work by teachers with established rubrics, the incorporation of external support staff to the evaluations, the self-assessment of the individual's contributions to the group, the penalty/bonus for the established deadlines accomplishment, etc.

All this has been carried out under the cover of the University of Zaragoza Teaching Innovation Projects in which the team has participated: PIIDUZ_09_3_127 / PIIDUZ_10_3_438 / PIIDUZ_11_3_482 / PIIDUZ_14_073 / PIIDUZ_14_069.

\section{Objectives of the study}

Although the technical quality of the module works evaluated by the team of teachers was very satisfactory, and even slightly increasing each year, the teaching team considered that it was time to make a qualitative leap and start to strengthen first, and then reward other fundamental aspects in the working world. Thus, as a result of the last revision of the system of quality guarantee in teaching and learning carried out in the past academic year 2015-2016, the teaching team decided to address two general objectives that remained unresolved until the date:

1st. Regarding the operation of the group:

Until 2015-2016 there was an evident area of improvement in the case of those groups that by their particular circumstances ended up developing internal conflicts that clearly affected their performance. The problem used to be difficult to find on time by the teaching team, since it was normally concealed by the members of the team until the internal coexistence became untenable or until the problem was manifested with a poor performance of the group being unable to present the complete work or qualified as ineligible.

2nd In relation to the recognition of individual internal work in the group:

For the teaching team there was another area that could be improved: rewarding the individual effort. In some groups there were people who clearly contributed with much less work than the average, and other people contributed with much more work than the average, being finally compensated all the people of the group with the same note. Which was not fair from the point of view of the teaching team.

In order to address these two areas of improvement in particular, the actions that were eventually developed respectively and in addition to the work that has been carried out, the decision was taken for the previous course of:

1st To implement a system of internal self-control on the operation of the group based on work meetings every two weeks made by the students. The results of these meetings should 
be reflected in meeting records in order to allow the teaching team to see their work evolution as well as to detect conflicts between members.

2nd To implement a system as objective as possible to reward the proactive behaviors and the leadership exercised by the students. This system is based on the information provided by the internal meeting records of the group, the individual surveys carried out by the team members and the perception of the team of teachers. The ultimate goal is to reward the work of team leaders through the score, as well as to punish the dishonest behavior of those members who did not cooperate in achieving the team's goals.

\section{Developed fieldwork}

The first week of the 15 that constitute the semester all the students of 2 nd grade and 2nd semester of the Degree in Engineering of of Industrial Design were distributed in working groups of 4 or 5 members to develop the MP. This MP consisted on the realization of a device for mental training. The 17 resulting groups were distributed among the members of the teaching team to be tutored more directly and personally.

Already in that first week the different teams of work carried out a meeting record of constitution of the team named denominates "Acta Cero" ("Zero Meeting Record"). The meeting records established the basis of the work or operating rules agreed by the team and the planning of activities for the whole term, both the MP and the subject (Market, Enterprise, Technology, Innovation and Communication). This meeting record, like the rest, that were later elaborated, was hung with the periodicity established in the teaching digital platform, in order to be supervised by the assigned tutor.

As already mentioned above, after the initial meeting records and every two weeks the different groups were elaborating 4 follow-up meeting records of the work done including the following points:

1. Degree of overall progress of the MP in percentage.

2. Degree of progress of each one of the areas or subjects in percentage.

3. Degree in which the knowledge of the 5 subjects has been integrated and related.

4. Degree of overall satisfaction with the development of the MP.

5. Degree of individual satisfaction with the development of the MP.

6. Individual assessment of the progress of work.

7. Need for an interview with the tutor / teaching team (optional).

Prior to the final presentation of the MP the group made the "Final Meeting Record" with an overall assessment of the MP. All of the above was especially supervised by the teachertutor responsible for the group as well as the rest of the team of teachers. 
After the public presentation of the works to the teaching team, the final assessment surveys and the individual contribution sheet fulfilled by the students, the teaching team made the assessment of the joint work of the different groups of students.

\section{Results}

The results finally obtained in relation to the internal functioning of the group, through the implementation of the system of internal self-control by the meeting records to be carried out on the work meetings every two weeks by the students, were the following:

- $\quad$ The meeting records done seemed to be generally agreed upon by team members and did not show that there were any problems. This might be probably true in most cases, but based on the previous experiences, it is quite possibly that the students, as colleagues, try to solve their problems internally rather than manifest them to the teaching team.

- There have been a number of problems in meeting delivery dates, especially due to the lack of attention of some groups. In some cases they were presented outside the system and in many others were not presented (which may indicate the existence of an internal problem). Although the records have served to take control, this has not been to the extent that the teaching team expected due to the problem described in the previous point. The first meeting record of constitution was made by all the groups (although two did it outside the system), but progressively and especially from the 3rd meeting record it was no longer answered by numerous groups. Of the 17 existing groups, they are only considered 16 for study purposes. Only 3 of the groups have answered all the acts. Table 1 shown below summarizes the general results, the number of responses obtained from within the system, not those carried out outside the system, as well as the degree of progress in the MP module work or in the several subjects.

- There seems to be a clear overall trend about the satisfaction shown by members of the different groups. In the first meeting records, they appear to be more demanding with the module project appearing numerous cases of people who say they are "neither satisfied nor dissatisfied" evolving to a greater presence of "somewhat satisfied" and "very satisfied" in the end. 


\begin{tabular}{|r|r|r|r|r|r|r|r|}
\hline \multirow{2}{*}{$\begin{array}{r}\text { MEETING } \\
\text { RECORDS }\end{array}$} & \multicolumn{2}{|c|}{ ANSWERS } & \multicolumn{6}{|c|}{ PROGRESS } \\
\cline { 2 - 8 } & $\mathbf{N}$ & $\begin{array}{c}\text { MAR- } \\
\text { KET }\end{array}$ & $\begin{array}{c}\text { ENTER- } \\
\text { PRISE }\end{array}$ & $\begin{array}{c}\text { TECHNO- } \\
\text { LOGY }\end{array}$ & $\begin{array}{c}\text { COMUNI- } \\
\text { CATION }\end{array}$ & $\begin{array}{c}\text { INNOVA- } \\
\text { TION }\end{array}$ \\
\hline 0 & 15 & 93,7 & & & & & \\
\hline 1 & 15 & 93,7 & 61,33 & 29,33 & 10,67 & 2,67 & 11,67 \\
\hline 2 & 14 & 87,5 & 89,29 & 48,57 & 25,36 & 23,21 & 45,36 \\
\hline 3 & 14 & 87,5 & 79,29 & 50,36 & 20 & 25,71 & 67,86 \\
\hline 4 & 9 & 56,2 & 88,33 & 56,67 & 29,44 & 42,78 & 75,56 \\
\hline 5 & 6 & 37,5 & 94,17 & 52,5 & 56,67 & 59,17 & 83,33 \\
\hline
\end{tabular}

Table 1. Acts prepared by groups of students

- About the usefulness of the system of the meeting records by the students, this year four questions were included in the final anonymous survey carried out on the module work. The results are shown in the following graph, which are evaluated on a scale of 1 to 7 , with 1 being "Totally disagree" and 7 "Totally agree" (see figure 1).

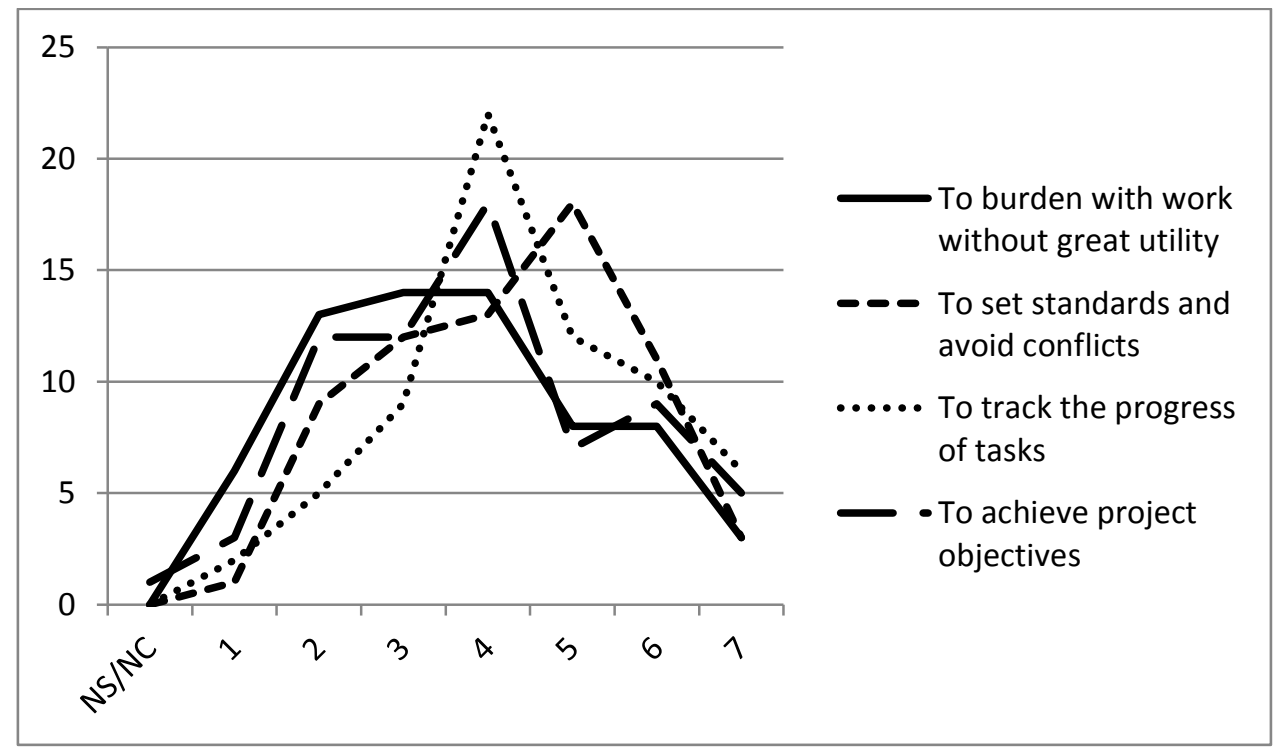

Figure 1: Assessment of the meeting record system by students

It can be seen that in general the students consider that the meeting records did not serve to load them of work without utility, but especially to establish the norms of the group and to avoid conflicts. Taking an intermediate position, the evaluation of the system to monitor the progress of work or achieve the objectives of the project. In relation to the recognition of individual leadership by establishing a system as 
objective as possible to reward the leadership exercised by students or punish dishonest behavior, this time has there was no need to apply it. Analyzing the information provided by the internal group meeting records, the individual surveys carried out by the different team members, the assessment sheet of the individual work, as well as the perception of the team of teachers, no significant cases were detected to be awarded as well as serious operating problems that deserve to be punished as dishonest behavior.

\section{Conclusions with pedagogical implications and continuity}

- Although it may be due to various causes, not attributable solely to the meeting record system with the planning carried out by the various groups, during the last year all 16 teams have completed the work satisfactorily in the advance examination call, with no fails as on previous occasions. Nonetheless, further work should be done to reduce the two peaks of work through planning that continue to be manifested. Similarly to the previous one, possibly due to various causes not attributable solely to the performance of the meeting records, this year there have been no serious operating problems that required the intervention of the teaching team. Neither dishonest behavior among colleagues of the same team has been detected.

Regarding the continuity of the project, the teaching team has taken the following agreements:

- To continue the following year with the system of meeting records reducing the number of the current 6 to 4 (constitution, prior to the intermediate presentation, agreements taken after the intermediate and final presentation).

- To give the meeting record a greater utility in piloting the groups and be more demanding in their implementation. Failure to submit them will prevent the submission of intermediate and final work.

- To continue with the improvement of the application of meeting records loading system, tutoring by responsible teacher, to extract answers to Excel and to visualize and analyze them.

- To add in the final survey a question on the individual assessment: Does it seem fair to you that all members of the group have the same grade? To which students must answer "Yes" or "No". In the case of answering "No" the student must propose a distribution of the score.

- To continue to study rewarding of the individual leadership through note. To do this, we are working on a system that is as objective as possible, by means of an algorithm that allows us to propose a distribution of the note. 


\section{References}

Agudo, J. M., López, I., Pardina, A., Sánchez, B., \& Sierra, J. (2010). Implantación de docencia por módulos en las asignaturas de $2^{\circ}$ Curso $2^{\circ}$ Cuatrimestre del Grado de Ingeniería de Diseño Industrial y Desarrollo de Producto. IV Jornadas de Innovación e Investigación Educativa de la Universidad de Zaragoza.

Agudo, J.M., López, I., Pardina, A., Sánchez, B., and Sierra, J. (2011). Docencia por módulos de asignaturas del Grado de Diseño Industrial y Desarrollo de Producto. Seguimiento y Mejora. 15 Congreso Internacional de Ingeniería de Proyectos. Huesca.

Bará, J., Ruiz, S., and Valero, M. (2009). Aprendizaje basado en Proyectos (Project Based Learning: PBL). Taller de formación impartido en el ICE de Zaragoza.

Bará J., Domingo, J., and Valero, M. (2009). Técnicas de aprendizaje Cooperativo. Taller de formación impartido en el ICE de Zaragoza.

Bouhuijs, P.A.J. (2011). Implementing Problem Based Learning: Why is it so hard? En REDU Revista de Docencia Universitaria. Vol.9 $\mathrm{n}^{\circ} 1$. Monográfico: "Aprendizaje basado en problemas".

Escudero, T. (2010). Diseño y Evaluación de Proyectos de Innovación Docente. Taller de formación impartido en el ICE de Zaragoza.

Escudero T. (2010). Algunos principios básicos sobre la programación de innovaciones educativas. Su diseño y evaluación. Formación del Profesorado. ICE de Zaragoza.

Herreroreder, I.A. (2013). Aprendizaje cooperativo en el ámbito de la Ingeniería: una experiencia de iniciación al Trabajo en Grupo. En REDU Revista de Docencia Universitaria.Vol.11 (Número especial, 2013)

López, I., and Manchado, E. (2009). Evaluación y divulgación de las acciones de innovación docente y de mejora de la docencia producidas a partir del estudio de resultados de encuesta de satisfacción a egresados. Prácticas y modelos innovadores para la mejora y calidad docencia. Prensas Universitarias de Zaragoza, Zaragoza.

López, I., and Manchado, E. (2013): Aprendizaje Modular: Integración de conocimientos en proyectos de ingeniería de diseño, en XXI Congreso Universitario de Innovación Educativa en las Enseñanzas Técnicas, Valencia.

Manchado, E., and López, I. (2012). Coordinación por módulos de asignaturas en el Grado de Ingeniería de Diseño Industrial y Desarrollo de Producto de la Universidad de Zaragoza. En REDU Revista de Docencia Universitaria.Vol.10 (3), Octubre-Diciembre 2012, $195-207$

Miralbes R., Auria J.M., Tardio E. y López I. (2011). Experiencia innovadora en la docencia de las asignaturas del grado de ingeniería de diseño industrial y desarrollo de producto basada en actividades multidisciplinares, Arbor, Vol 187, No Extra_3

Sánchez, B. (2012). Aprendizaje de Estadística basado en Proyectos. Dos casos prácticos. Uno (Revista de didáctica de las Matemáticas) 59: 40-45, Ene. 2012

Serrano, A., Hernández, M., Pérez, E., and Biel, P. (2013). Trabajo por módulos: un modelo de aprendizaje interdisciplinar y colaborativo en el Grado en Ingeniería en Diseño Industrial y Desarrollo de Producto. En REDU Revista de Docencia Universitaria.Vol.11 (Número especial, 2013), 197-220. 